\title{
The Interactive Role Using the Mozabook Digital Education Application and its Effect on Enhancing the Performance of eLearning
}

\author{
https://doi.org/10.3991/ijet.v15i20.17101 \\ Duha Khalid Abdul-Rahman Al-Malah ${ }^{(凶)}$, Saad Ibrahim Hamed \\ Northern Technical University, Mosul, Iraq \\ duhakmentu.edu.iq \\ Haider TH. Salim ALRikabi \\ Wasit University, Wasit, Iraq
}

\begin{abstract}
This study examines the impact of the use of the Mozabook application for digital education on enhancing the performance of electroniclearning to ensure strategic educational success. It highlights the urgent need for using eLearning to increase and enable scientific knowledge to confront the exceptional circumstances that afflict the world in general and Iraq in particular, in view of the spread of the Corona pandemic and its harm to society. The study aims to find better methods that enhance the role of digital education in creating a knowledgeability that meets the requirements of the educational process. These requirements range from methodological content, educational methods and study tools such as blackboard, notebook, drawing tools to scientific, engineering, chemical, biological, geographic, historical laboratories and other requirements that attract the student and his eagerness to engage in the digital education. Therefore, an application that works with three-dimensional technology was chosen with the availability of all audio, visual, and sensory means to increase the interaction and desire of the student for the scientific subject.
\end{abstract}

Keywords-Mozabook, eLearning, Technology, Educational Environment, Smartboard, Educational content.

\section{Introduction}

The world-wide rapid changes in the technical, economic, cultural, social, and scientific realms have led to the emergence of new innovations. Chief among these have been in the material and cognition fields that came to the fore in the modern era (e.g. in artificial intelligence, interactive, and connectivity) with a meaningful change in the modern education environment. The digital education looks to create new opportunities for educational work through the availability of high accuracy and great speed in providing information to students. It also seeks to improve the skills, experiences, and capabilities of students, and their transition from the age of data and 
information to the age of knowledge and knowledge-ability, which concerns the capabilities and the high potential for interaction between the teacher and the student. This enables the student to engage in digital education as it holds alternatives identical to the reality $[1,2]$.

In this study, we look to determine the effectiveness of the use of the virtual class Mozabook and its role in enhancing the performance of eLearning. This has been one of the recent and important needs that have appeared in recent times because of the difficult circumstances the country is going through (Corona pandemic) and the continuation of education under such circumstances.

The study assesses several major hypotheses, which determine whether there is a significant effect of the application of the Mozabook digital education on eLearning. In this light, we selected academics and students affiliated with the Ministry of Higher Education and Scientific Research who were given a questionnaire to complete. We performed a statistical analysis of the results using several statistical methods such as arithmetic mean, standard deviation, correlation coefficient, regression coefficient, and path analysis.

\section{$2 \quad$ Literature Review}

eLearning is a type of education that relies on the use of communication and information technology to design and produce digital education tools. The goal of eLearning is to ensure the educational process as an alternative to traditional education. It therefore eases communication with students and provides them with opportunities for proper distance education that achieves equality and justice among all groups of students [3]. In addition, it is also defined as a type of education that depends on the use of electronic media to fulfill several functions. These range from communicating and receiving information to acquiring skills, and interactions between the student and the teacher on the one hand, and between the student and the school on the other. This type of education does not require the presence of school buildings or classrooms, but rather, eliminates all components of physical education [4-7].

In [8-11], it is also defined as "a type of virtual education by its means, realistic with its results. This type is related to electronic means and information and communication networks, the most famous of which is the International Information Network (Internet), which has become an effective medium for electronic education". $[12,13]$ referred to eLearning as "the use of technology and technological means in education by relying on them as an integrated educational system, and harnessing it to the student's self and collective learning and making it the focus of the educational process".

The procedural definition holds that it is an education and modern technical learning that encompasses all the requirements of the educational system. These concern curricula, educational decisions, educational processes, places, and classrooms, with information and communication technology to ease the communication and spread of information more quickly and at a lower cost. The 
modern technology includes learning process management systems, learning content management systems, software authoring tools, training transfer, transmission and publishing systems, educational software, video programs [14-16]. In addition, some scholars define it as a program designed to organize and manage teaching and learning processes that usually take place in the classroom, enabling these environments to be called electronic classes [17, 18]. Moreover, eLearning provides a huge collection of databases including eBooks, electronic journals, scientific projects, interactive video clips, information data [19-23]. Several studies [24-26] have compared face to face methods that employ email or internet chat rooms in performing electronically-administered teaching and online learning in order to determine which of these formats provides, for example, the highest learning outcome, the highest rate of student satisfaction or has the highest rate of course completion. In their study on a school in Nusa Dua Padung, Bali, [37] examined the effect of computer-assisted assessment (CAA) on students and how it enhances their achievement in learning aspects of vocabulary and laboratory grammar, and language learning skills. It was found that E-learning enabled them to express themselves and describe their abilities. Therefore, the authenticity of grading was ascertained as every question was displayed on the screen randomly, which made it difficult for students to copy the answers from their mates.

\section{Mozabook (Concepts, Specifications, and Dimensions)}

\subsection{The concepts of Mozabook}

Mozabook is defined as a digital educational system designed specifically to facilitate the work of teachers according to their needs. It also covers the entire educational system for each subject and provides proper support for both students and parents $[28,29]$. It is also defined as an interactive educational presentation program that could teach easily and expressively. Through Mozabook, digital books can be shown and supplemented with digital contents (videos, sounds, 3D models, exercises), through program recommendations in a few movements. Firstly, it can be prepared for interesting presentations, teaching schemes, and exercises that excite students and help them understand the topic more easily [30]. Secondly, it is an optimal display program for interactive writing boards and presentations. In addition, Digital publications make printed materials from books more interesting and easier to understand, with various interactive materials, 3D samples, educational videos, exercises, and thematic tools [29, 31]. Finally, it is a process of learning from digital textbooks with interactive 3D scenes, educational videos, and exercises, as it contains elements for developing the students' skills and perceptions and facilitates the process of acquiring knowledge using feedback and direct interaction between the teacher and the student as in Figure 1. 


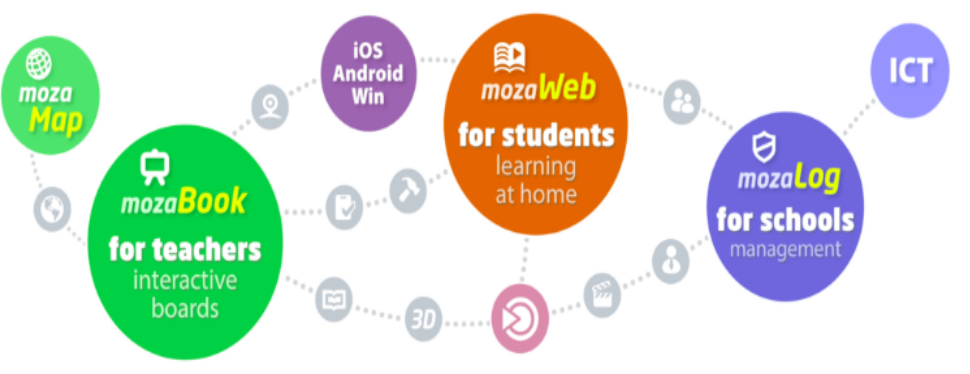

Fig. 1. The Mozabook digital system

\subsection{Mozabook educational specifications}

1. The interactive content of the program and its laboratory applications with the presence of explanatory tags can help in arousing the interest of students and acquiring knowledge.

2. Teachers can create their presentations or convert their study files into interactive digital books with just a few clicks. They can also enrich books and digital presentations with images, graphics, and interactive 3D models, in addition to custom worksheets created with the built-in test editor in Mozabook [32, 33].

3. A simple and intuitive application that considers teachers' comments during development, so the program is easy to use. Moreover, jobs can be found in the place that users expect.

4. A social system that can share exercise books and worksheets created in Mozabok at the school or international level. This in turn allows teachers to access exercise books and worksheets and use them in the classroom.

5. It can open PDF documents, allowing the user to process the PDF file as you would on a regular computer, make it the basis for your presentation and convert it into digital publications. This is done easily by adding interactive content from the library media in a few simple steps.

6. Settling (multilingual), Mozabook provides compact applications, educational videos, interactive 3D samples and their readers come in many languages, and their number is constantly increasing [34-36].

7. A comprehensive platform network to ease home education using mobile education (using small wireless devices). Figure 2 shows the interface of the Mozabook application. 


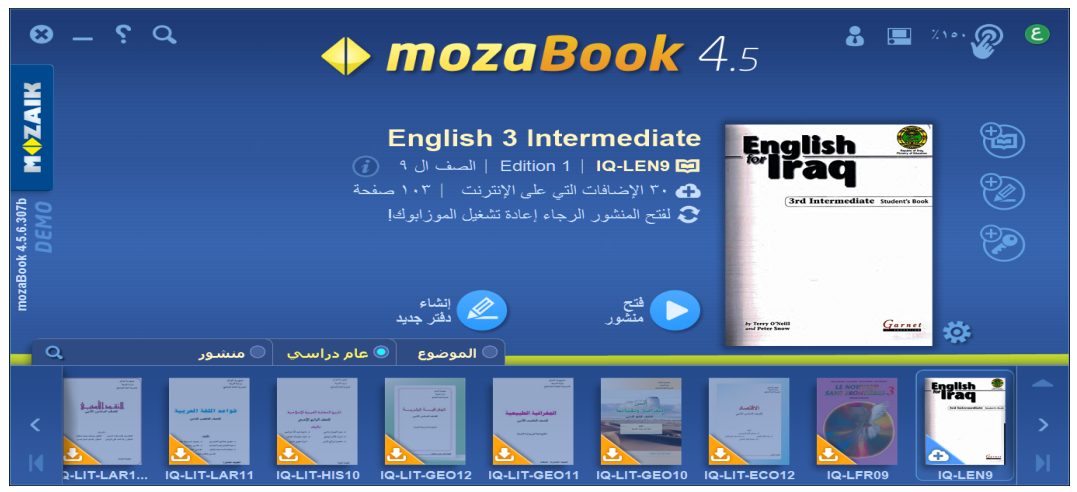

Fig. 2. The interface of the Mozabook application

\subsection{Dimensions of Mozabook digital education}

Smartboard: This is a blackboard built from the strategy of artificial intelligence. It has electronic boards designed to display the visual and audio texts that are sent to students, through which it is possible to open more than one book or subject at a time. The professor can comfortably and adequately plan and create lessons to enrich the textual simulation [9].

Dynamic additions: These mean the multimedia available within the application, represented by (images, media library, 3D samples, animation wall) [10].

Applied tools: Theoretical application tools can be used for the academic subject in addition to having the practical application tools as well as the presence of several other tools and materials. These include virtual experimental tools, time machine tools, drawing tools, mechanical tools, electronic calculator, charts, mathematical functions, engineering drawings, biological, physical, and chemical laboratories [11].

Exercises and homework: The teacher can create and edit exercises, whether e.g. they are optional or otherwise and prepare them appropriately so that the student can answer the questions asked electronically.

Evaluations: The answers presented by the student and the results can be seen immediately after the exam, as well as the relative statistics for the marks can be obtained [30, 37].

\section{$4 \quad$ Study Method}

\subsection{The significance of the study}

This study looks to fulfill some of the requirements of the current and future educational administration that directs towards the optimal implementation of digital education according to the talents and capabilities of teachers. This can be obtained through its basic engine, which is the human mind and the extent of its knowledgeability to ensure the success of eLearning at the present time. 


\subsection{The aims of the study}

The study is a theoretical and practical attempt to analyze the relationship between digital education and eLearning and measure the extent of their ability to ensure the success of the educational process. In this study, we look to address this issue and achieve the following goals:

1. Determining the effect of the study variables (digital and eLearning).

2. Emphasizing the use of digital education to generate, implement and transfer knowledge.

3. Seeking to find the leadership ability to build the educational system and take over the process of managing all activities related to managing the educational process.

4. Working to spread internal knowledge in labor affairs to overcome weaknesses and achieve the success of eLearning.

\subsection{The hypothetical study plan}

Figure 3 shows the study plan of the present study.

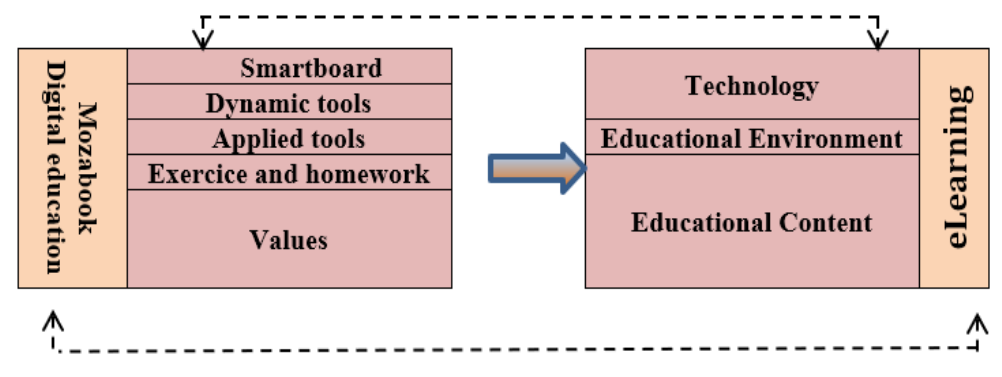

Fig. 3. The study plan of the present study

\subsection{Study hypotheses}

In this study, several major and minor hypotheses were formulated and as follows:

The first hypothesis: This hypothesis proposes that there is a significant correlation between digital education Mozabook and eLearning in the field of study from which the following sub-hypotheses can be formulated:

1. There is a significant effect of smartboard on eLearning

2. There is a significant correlation between dynamic additions and eLearning

3. There is a significant correlation between the applied tools and eLearning

4. There is a significant correlation between exercises, homework, and eLearning

5. There is a significant correlation between evaluation and eLearning 
The second hypotheses: In this hypothesis, we suggest that there is a significant effect of Mozabook digital education on eLearning, and the following sub-hypotheses can be formed:

1. There is a significant effect of Mozabook digital education particularly books and publications on eLearning. The student can choose the method to display the curriculum in word, PDF, etc. In addition, the student can enjoy browsing possibilities of the paper book. Moreover, the student can borrow the book that he/she wanted from the electronic library, the storage media at his computer, and from the internet.

2. There is a significant effect of digital education, Mozabook, dynamic additions, on electronic education.

3. There is a significant effect of digital education, Mozabook, applied tools on eLearning.

4. There is a significant effect of digital education, Mozabook, exercises, and homework on eLearning.

5. Existence of a significant effect of Digital Education Mozabook evaluations on eLearning

\subsection{The method of the study}

In this study, we adopted a descriptive and analytical method to:

i. Achieve the goals of the study

ii. Answer the questions

iii. Choose hypotheses through the theoretical and practical strands of the study to establish the link between them by study and analysis.

\subsection{The limits of the study}

The main limits of the study can be presented as follows:

- Knowledge frontiers - the study examined both the digital and electronic education for students of the Tourism Department.

- Spatial limits - The study was completed at Northern Technical University, Iraq.

- Temporal limits - the study was conducted during the period 18/3/2020 until 14/7/2020.

- Human frontiers - In our study, we adopted a survey of teachers' opinions as human limits for the current study.

\subsection{The study sample}

To achieve the goals of the study, the research sample was chosen to test the variables and the hypothetical model based on sound scientific foundations of the field. Therefore, university academics and students of the Department of Tourism and 
Hotel Management of the university were chosen. The questionnaire was distributed electronically in Form format, which was created on Google Drive. We received 77 completed questionnaires that were valid for testing.

\subsection{Data collection techniques}

Primary and secondary data collection techniques were adopted to fulfill the goals of the study, both theoretically and practically. The secondary data were chosen from sources related to the variables of the study to set up theoretical frameworks. The primary data collected through the electronic questionnaire form stood for the components of digital education from smartboard, dynamic additions, application tools, exercises and homework, evaluation. The eLearning variables were represented by technology, educational environment, and educational content.

\section{The Demographic Variables of the Study}

These variables give a demographic description of the individuals recruited for the study sample. In Figure 4, we can notice the following:
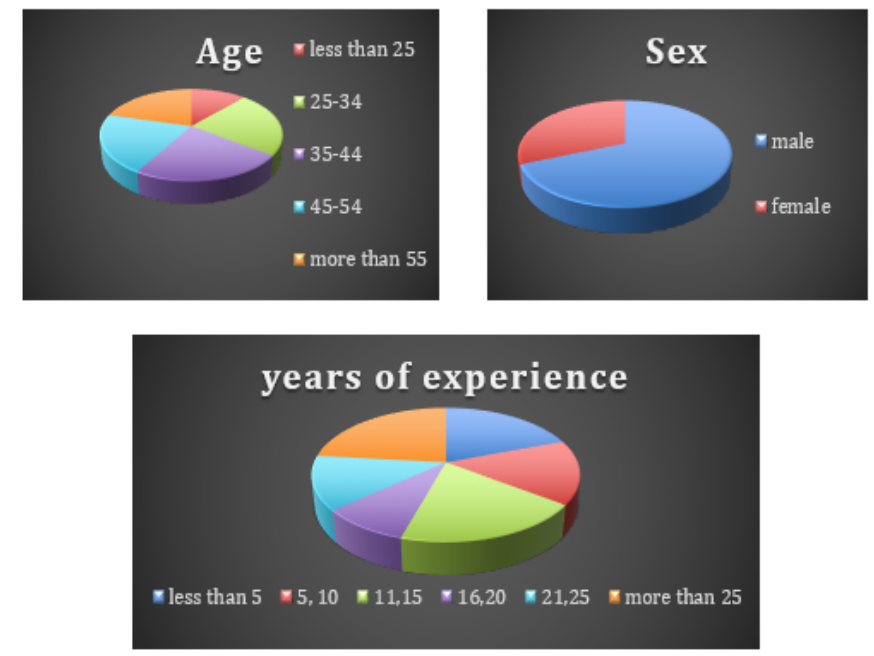

Fig. 4. The age, gender, and the number of years of service

Thus, we can notice that:

1. Regarding the age groups, the highest frequency was $23.4 \%$ for the age group that ranges between 35 and 44 .

2. Concerning the gender variable, where male recurrence was the highest, at $68.8 \%$, while female repetition was $31.2 \%$. 
3. Concerning the years of experience variable, the highest frequency was for the category of over 25 years, at $23.4 \%$.

\section{The Stability of the Questionnaire}

The stability of the questionnaire means that the constancy of the scale used will give the same results and with an equal probability to the value of the coefficient of Cronbach's Alpha if it is repeated to the same sample. The stability of the questionnaire used was conducted by repeating the questionnaire to the same sample multiple times in the same circumstances and as shown in Table (1). In this table, we can note that the value of the coefficient of stability for the Mozabook application is 0.945 , which means that the stability of this questionnaire is $94.5 \%$, and this is considered a positive indicator. The stability of smartboard is 0.789 , while for the after dynamic additions, it is 0.829 . For after the application tools, it is 0.771 , and after the exercises and duties, it is 0.87 , while after the evaluations, it stood at 0.868 . The number of questions in these the questionnaire for Mozabook application is 20 questions. As for the dimensions of eLearning, the stability for the technology dimension is 0.85 , the educational environment is 0.847 , and the educational content is 0.84 . The coefficient of persistence for eLearning is 0.912 , meaning that the stability of the questions of this questionnaire is $91.2 \%$, and this is considered a positive indicator. The results of the analysis of the responses from the study sample for the Mozabook application in Table (2) shows that the arithmetic means for its dimensions is (3.83). It also shows that the standard deviation is (0.589), while the relative importance is $(76.6 \%)$ where the response direction is (agreed). Therefore, paragraph (2) appears to be the most contributing to the enrichment of this dimension, as it obtained arithmetic mean of (3.922) and a standard deviation of (0.687) with a relative importance of (78.4\%), where the answer was (agreed). Table (2) shows that the mean for the electronic learning is (3.85) and that the standard deviation is (0.732) while the relative importance is (77\%), as the direction of the answer is (agreed). It also shows that after the learning environment is the highest in terms of the arithmetic mean (3.99) and that the standard deviation is (0.701), while the relative importance is (79.8\%), as the direction of the answer is (agreed). 
Table 1. Results of the internal consistency test for the variables

\begin{tabular}{|c|c|c|c|}
\hline The Scale & $\begin{array}{l}\text { Alpha Cronbach of } \\
\text { dimensions }\end{array}$ & $\mathbf{N}$ & $\begin{array}{l}\text { Alpha Cronbach of the } \\
\text { axis }\end{array}$ \\
\hline MoozaBook & & 20 & \multirow{6}{*}{0.945} \\
\hline Smart board & 0.789 & 4 & \\
\hline Dynamic tools & 0.829 & 4 & \\
\hline Applied tools & 0.771 & 4 & \\
\hline Exercises and homework & 0.87 & 4 & \\
\hline Values & 0.868 & 4 & \\
\hline \multicolumn{2}{|c|}{ eLearning } & 12 & \multirow{4}{*}{0.912} \\
\hline Technology & 0.85 & 4 & \\
\hline Educational Environment & 0.847 & 4 & \\
\hline Educational Content & 0.84 & 4 & \\
\hline
\end{tabular}

Table 2. The sample description for the applications axes, Moozabook and eLearning axis

\begin{tabular}{|c|c|c|c|c|}
\hline Paragraphs & \begin{tabular}{l|} 
Standard \\
Deviation
\end{tabular} & $\begin{array}{c}\text { Arithmetic } \\
\text { Mean }\end{array}$ & $\begin{array}{c}\text { Relative } \\
\text { importance } \%\end{array}$ & $\begin{array}{c}\text { Answer } \\
\text { Direction }\end{array}$ \\
\hline \multicolumn{5}{|c|}{ Mozabook Applications } \\
\hline \multicolumn{5}{|c|}{$\begin{array}{ll}\text { Smart board } \\
\end{array}$} \\
\hline $\begin{array}{l}\text { 1-Ease of opening and selecting the new } \\
\text { educational book or publication using the book } \\
\text { interface or by importing the book in PDF or PPT } \\
\text { format. }\end{array}$ & 0.788 & 3.78 & 75.6 & Agree \\
\hline $\begin{array}{l}\text { 2-You can choose and open more than one material } \\
\text { study at a time and exchange between them by } \\
\text { clicking on it only. }\end{array}$ & 0.898 & 3.66 & 73.2 & Agree \\
\hline $\begin{array}{l}\text { 3-Save the material study as Mozabook copybook } \\
\text { after adding the educational activity to it in a } \\
\text { smooth and simple way by clicking on the icon } \\
\text { from the taskbar. }\end{array}$ & 0.75 & 3.74 & 74.8 & Agree \\
\hline $\begin{array}{l}\text { 4-The variety of drawing tools available in the } \\
\text { smart board arouses the desire of the student to } \\
\text { learn. }\end{array}$ & 0.785 & 3.83 & 76.6 & Agree \\
\hline & 0.632 & 3.75 & 75 & \\
\hline \multicolumn{5}{|c|}{ Dynamic tools } \\
\hline $\begin{array}{l}\text { 1-The additional content makes the lessons more } \\
\text { exciting and increases the level of clarification, } \\
\text { which makes the teaching process more successful. }\end{array}$ & 0.916 & 3.71 & 74.2 & Agree \\
\hline $\begin{array}{l}\text { 2-Adding 3D models to embody the shape or } \\
\text { drawing with the possibility of rotating. it in all } \\
\text { directions and seeing the internal contents of the } \\
\text { shape. }\end{array}$ & 0.843 & 3.88 & 77.6 & Agree \\
\hline $\begin{array}{l}\text { 3-Videos and documentaries can be added to } \\
\text { explain scientific experiments, also, to the } \\
\text { possibility of incorporating music, pictures, and } \\
\text { plans for the educational subject. }\end{array}$ & 0.833 & 4.13 & 82.6 & Agree \\
\hline \multirow[t]{2}{*}{$\begin{array}{l}\text { 4-Ability to automatically complete the open } \\
\text { publication and PDF files with posts related to } \\
\text { additional content. }\end{array}$} & 0.785 & 3.96 & 79.2 & Agree \\
\hline & 0.687 & 3.922 & 78.4 & \\
\hline \multicolumn{5}{|c|}{ Applied tools } \\
\hline
\end{tabular}




\begin{tabular}{|c|c|c|c|c|}
\hline $\begin{array}{l}\text { 1-He possesses all the theoretical tools used, such } \\
\text { as a pen, notebook, eraser, calculator, colors and } \\
\text { graphic sheets, that enables the teacher to create an } \\
\text { integrated theoretical lecture. }\end{array}$ & 0.812 & 3.84 & 76.8 & Agree \\
\hline $\begin{array}{l}\text { 2-He has all the laboratory, engineering, biological, } \\
\text { chemical and temporal scientific tools to enable the } \\
\text { teacher to create a complete practical laboratory. }\end{array}$ & 1.04 & 3.58 & 71.6 & Agree \\
\hline $\begin{array}{l}\text { 3-It has completed virtual experimental tools, } \\
\text { biological, physical, chemical, human, plant, } \\
\text { historical and geographical sections and all the } \\
\text { teaching needs to add to the book or exercises and } \\
\text { duties. }\end{array}$ & 0.851 & 3.56 & 71.2 & Agree \\
\hline $\begin{array}{l}\text { 4- Ease of search and operation of dynamic } \\
\text { additions, with the ability to display in miniature or }\end{array}$ & 0.803 & 3.94 & 78.8 & Agree \\
\hline & 0.679 & 3.74 & 74.8 & \\
\hline \multicolumn{5}{|c|}{ Exercice and homework } \\
\hline $\begin{array}{l}\text { 1-With the help of the Exercise Editor, you can } \\
\text { prepare various interesting exercises and you can } \\
\text { create a set of different exercises. }\end{array}$ & 0.75 & 3.83 & 76.6 & Agree \\
\hline $\begin{array}{l}\text { 2- The exercises have different styles so that the } \\
\text { teacher can edit and create exercises in many types, } \\
\text { including easy choices and complex mapping } \\
\text { exercises. }\end{array}$ & 0.828 & 3.84 & 76.8 & Agree \\
\hline $\begin{array}{l}\text { 3-It contains ready-made exercise templates to } \\
\text { create assignments with different structures and } \\
\text { arrangements in each task type. }\end{array}$ & 0.854 & 3.81 & 76.2 & Agree \\
\hline $\begin{array}{l}\text { 4-Ease of changing and revising exercises, } \\
\text { presenting them in an interesting and flowery }\end{array}$ & 0.839 & 3.82 & 76.4 & Agree \\
\hline & 0.695 & 3.82 & 76.4 & \\
\hline \multicolumn{5}{|c|}{ Values } \\
\hline $\begin{array}{l}\text { 1-Ease of obtaining exam instructions for } \\
\text { instructions and educational schedules. }\end{array}$ & 0.854 & 3.86 & 77.2 & Agree \\
\hline $\begin{array}{l}\text { 2-Have ready-made templates and forms for } \\
\text { presentation of examination result. }\end{array}$ & 0.844 & 3.81 & 76.2 & Agree \\
\hline $\begin{array}{l}\text { 3-The possibility of displaying the test result } \\
\text { immediately after completing the exam. }\end{array}$ & 0.819 & 4.01 & 80.2 & Agree \\
\hline $\begin{array}{l}\text { 4-Display the correct and wrong answers, the } \\
\text { divided score for each the question, the sum of the }\end{array}$ & 0.866 & 3.99 & 79.8 & Agree \\
\hline & 0.715 & 3.91 & 78.2 & \\
\hline & 0.589 & 3.83 & 76.6 & \\
\hline \multicolumn{5}{|c|}{ eLearning } \\
\hline \multicolumn{5}{|c|}{ Technology } \\
\hline $\begin{array}{l}\text { 1- Educational management systems contribute to } \\
\text { the smooth performance of homework and training. }\end{array}$ & 0.843 & 4.03 & 80.6 & Agree \\
\hline $\begin{array}{l}\text { 2- The level of technical support provided in the } \\
\text { system that provides immediate assistance or direct } \\
\text { response. }\end{array}$ & 0.865 & 3.83 & 76.6 & Agree \\
\hline $\begin{array}{l}\text { 3- Students can use the eLearning system } \\
\text { individually or in groups. }\end{array}$ & 0.827 & 3.88 & 77.6 & Agree \\
\hline $\begin{array}{l}\text { 4- Provides the support infrastructure to employ } \\
\text { ICT in teaching. }\end{array}$ & 0.984 & 3.65 & 73 & Agree \\
\hline
\end{tabular}




\begin{tabular}{|c|c|c|c|c|}
\hline & 0.62 & 3.87 & 77.4 & \\
\hline \multicolumn{5}{|c|}{ Educational Environment } \\
\hline $\begin{array}{l}\text { 1- My lack of knowledge of managing virtual } \\
\text { classes leads to less benefit from eLearning. }\end{array}$ & 0.899 & 3.82 & 76.4 & Agree \\
\hline $\begin{array}{l}\text { 2- Using eLearning at an early age, capable of } \\
\text { guiding the student towards a scientific use of } \\
\text { computers. }\end{array}$ & 0.823 & 4.14 & 82.8 & Agree \\
\hline 3- The lack of time to use the eLearning system. & 0.841 & 3.95 & 79 & Agree \\
\hline \multirow[t]{2}{*}{$\begin{array}{l}\text { 4- Provides good opportunities to practice } \\
\text { speaking, discussing and listening skills. }\end{array}$} & 0.826 & 4.05 & 81 & Agree \\
\hline & 0.701 & 3.99 & 79.8 & \\
\hline \multicolumn{5}{|c|}{ Educational Content } \\
\hline $\begin{array}{l}\text { 1- The content of the database, including the } \\
\text { electronic books and magazines it contains, enables } \\
\text { the teacher and the student to demonstrate his } \\
\text { intellectual and intellectual capabilities. }\end{array}$ & 0.916 & 3.95 & 79 & Agree \\
\hline $\begin{array}{l}\text { 2- eLearning platforms and portals increase the } \\
\text { interaction between teacher and learner. }\end{array}$ & 0.946 & 3.81 & 76.2 & Agree \\
\hline $\begin{array}{l}\text { 3- LCM eLearning content tools are subsections of } \\
\text { the teacher's and learner's electronic educational } \\
\text { classes. }\end{array}$ & 0.825 & 3.71 & 74.2 & Agree \\
\hline \multirow[t]{3}{*}{$\begin{array}{l}\text { 4- LCMS eLearning content tools are the total parts } \\
\text { of eLearning classrooms for teacher and learner. }\end{array}$} & 0.823 & 3.65 & 73 & Agree \\
\hline & 0.723 & 3.78 & 75.6 & \\
\hline & 0.732 & 3.85 & 77 & \\
\hline
\end{tabular}

\section{$7 \quad$ Testing the Hypotheses of the Study}

The study tests the hypothesis which states that there is a significant effect of Mozabook on eLearning.

H0: There is no significant correlation between Mozabook digital education and eLearning.

H1: There is a significant correlation between Mozabook digital education and eLearning.

The Sub-hypotheses run as follows:

1. There is a significant correlation between smartboard and eLearning.

2. There is a significant correlation between dynamic additions and eLearning.

3. There is a significant correlation between the applied tools and eLearning.

4. There is a significant correlation between exercises, homework, and eLearning.

5. There is a significant correlation between evaluation and eLearning. 
Table 3. The relations of association

\begin{tabular}{|l|l|c|c|c|c|c|c|}
\hline & & $\begin{array}{c}\text { Smart } \\
\text { board }\end{array}$ & $\begin{array}{c}\text { Dynamic } \\
\text { additions }\end{array}$ & $\begin{array}{c}\text { Applied } \\
\text { tools }\end{array}$ & $\begin{array}{c}\text { Exercises \& } \\
\text { Homework }\end{array}$ & Values & Mozabook \\
\hline \multirow{4}{*}{ eLearning } & $\begin{array}{l}\text { Pearson } \\
\text { Correlation }\end{array}$ & $0.609^{*}$ & $0.657^{*}$ & $0.690^{*}$ & $0.620^{*}$ & $0.637^{*}$ & $0.744^{*}$ \\
\cline { 2 - 8 } & Sig.(2-tailed) & 0.000 & 0.000 & 0.000 & 0.000 & 0.000 & 0.000 \\
\cline { 2 - 8 } & $\mathrm{N}$ & 77 & 77 & 77 & 77 & 77 & 77 \\
\hline
\end{tabular}

*. Correlation is significant at the 0.01 level (2-tailed).

Table (3), indicates that there is a significant correlation between Mozabook and eLearning in the study sample. This is manifested in the significant value of the Pearson correlation coefficient; equal (0.744) since the significant value is equal to (0.000), which is less than 0.01 with $99 \%$ confidence. This means that the first main hypothesis is fulfilled, meaning there is a significant correlation between Mozabook and eLearning.

As for the Sub-hypotheses, it was found that there is a significant correlation between the applied tools and eLearning where the correlation value is $(0.690)$ since the significant value is $(0.000)$, which is less than 0.01 with $99 \%$ confidence. A significant correlational relationship between smartboard, and eLearning was also found where the correlation value is $(0.609)$ because the significant value is $(0.000)$ which is less than 0.01 with $99 \%$ confidence. It was also found that there is a significant correlation between dynamic additions and eLearning where the correlation value is $(0.657)$ as the correlative value is $(0.000)$, which is less than 0.01 with $99 \%$ confidence. There is also a significant correlation between exercises, homework, and eLearning where the correlation value is $(0.62)$ as the significant value is $(0.000)$, which is less than 0.01 with $99 \%$ confidence. It was also found that there is a significant correlation relationship between evaluation and eLearning where the correlation value is $(0.637)$ as the significant value is equal to $(0.000)$, which is less than 0.01 with $99 \%$ confidence.

This hypothesis states that here is a significant effect of Mozabook digital education on eLearning in the field of study, and the following sub-hypotheses are formed, as follows:

1. There is a significant effect of Mozabook between smartboard and eLearning.

2. There is a significant effect of Mozabook between dynamic additions and eLearning.

3. There is a significant impact of Mozabook between applied tools on eLearning.

4. There is a significant effect of Mozabook between exercises and homework on eLearning.

5. There is a significant effect of Mozabook between evaluations on eLearning. 
Table 4. Shows the explanatory power of the model

\begin{tabular}{|c|c|c|c|c|}
\hline \multicolumn{5}{|c|}{ Model Summary } \\
\hline Model & $\mathrm{R}$ & R Square & Adjusted R Square & $\begin{array}{c}\text { Std. An error of the } \\
\text { Estimate }\end{array}$ \\
\hline 1 & $.744^{\mathrm{a}}$ & .554 & .548 & .49227 \\
\hline
\end{tabular}

a.Predictors: (Constant), Mozabook

From Table 4, we can notice that the value of correlation (R) is 0.77 and that the explanatory power of the model (R2) is 0.554 . This means that the Mozabook digital education application has explained (55.4\%) of the changes that occur to eLearning.

Table 5. The impact of the Mozabook application on eLearning

\begin{tabular}{|c|c|c|c|c|c|c|}
\hline \multicolumn{7}{|c|}{ Coefficients } \\
\hline & \multirow{2}{*}{ Model } & \multicolumn{2}{|c|}{ Unstandardized Coefficients } & \multirow{2}{*}{$\begin{array}{c}\begin{array}{c}\text { Standardized } \\
\text { Coefficients }\end{array} \\
\text { Beta }\end{array}$} & \multirow{2}{*}{$T$} & \multirow{2}{*}{ Sig. } \\
\hline & & $B$ & Std. Error & & & \\
\hline \multirow{2}{*}{1} & (Constant) & .299 & .372 & & .806 & .423 \\
\hline & Mozabook & .926 & .096 & .744 & 9.656 & .000 \\
\hline
\end{tabular}

a. Dependent Variable: eLearning

Table 5 shows that the effect value has reached $\mathrm{B}=(0.926)$, meaning that the increase in Mozabook digital education with one unit of standard deviations will lead to an increase in achieving the competitive advantage by $92.6 \%$ of the unit of standard deviation.

Table 6. The analysis of contrast

\begin{tabular}{|c|l|c|c|c|c|c|}
\hline \multicolumn{7}{|c|}{ ANOVA } \\
\hline \multicolumn{2}{|c|}{ Model } & Sum of Squares & Df & Mean Square & $\boldsymbol{F}$ & Sig. \\
\hline \multirow{3}{*}{1} & Regression & 22.594 & 1 & 22.594 & 93.237 & $.000^{\mathrm{b}}$ \\
\cline { 2 - 7 } & Residual & 18.175 & 75 & .242 & & \\
\cline { 2 - 7 } & Total & 40.769 & 76 & & & \\
\hline
\end{tabular}

a.Dependent Variable: Learning

b.Predictors: (Constant), Mozabook

The results of the $\mathrm{F}$ test indicate an effect of the dimensions of the Mozabook application on enhancing the performance of eLearning, as shown in Table (6). In this table, the calculated value of $F$ is (93.237) at the significance level of $(0.05)$. The value of P-value is equal to $(0.00)$, which is less than 0.05 . This means rejecting the null hypothesis and accepting the alternative hypothesis and consequently there is an effect to exclude the application of the Mozambique digital education to eLearning. 
Table 7. The coefficient of inflation and multiple linear regression

\begin{tabular}{|c|c|c|c|c|c|c|c|c|}
\hline \multicolumn{9}{|c|}{ Coefficients } \\
\hline & \multirow[t]{2}{*}{ Model } & \multicolumn{2}{|c|}{$\begin{array}{c}\text { Unstandardized } \\
\text { Coefficients }\end{array}$} & \multirow{2}{*}{$\begin{array}{c}\text { Standardized } \\
\text { Coefficients }\end{array}$} & \multirow[t]{2}{*}{$\boldsymbol{T}$} & \multirow[t]{2}{*}{ Sig. } & \multicolumn{2}{|c|}{ Collinearity Statistics } \\
\hline & & $B$ & Std. Error & & & & Tolerance & $V I P$ \\
\hline \multirow{6}{*}{1} & (Constant) & .201 & .377 & & .533 & .596 & & \\
\hline & Smart board & .204 & .131 & .176 & 1.549 & .126 & .457 & 2.190 \\
\hline & Dynamic additions & .243 & .151 & .228 & 1.607 & .113 & .292 & 3.430 \\
\hline & Applied tools & .437 & .122 & .405 & 3.593 & .001 & .461 & 2.170 \\
\hline & Exercises \& Assignments & .023 & .145 & .021 & .156 & .877 & .310 & 3.231 \\
\hline & Values & .098 & .139 & .096 & .703 & .484 & .318 & 3.148 \\
\hline
\end{tabular}

a. Dependent Variable: eLearning

Table (7) shows that the value of Sig. of smartboard equals 0.126 , which is greater than 0.05 and indicates that the first sub-hypothesis was not fulfilled. Also, it shows that the value of Sig. of dynamic additions equals 0.113 , which is greater than 0.05 , and indicates that the second sub-hypothesis was not fulfilled. It also the applied tools' value of Sig. equals 0.001 , which is less than 0.05 , and the effect value $(\mathrm{B}=$ 0.437). This means the increase in the applied tools variable with one unit of standard deviations will lead to an increase in achieving the competitive advantage by $43.7 \%$ of the standard deviation unit. This indicates the verification of the third subhypothesis. Moreover, the table shows that the value the effect of exercises and homework equals 0.877 , which is greater than 0.05 . This indicates that the fourth hypothesis was not fulfilled. Finally, the significance value of the assessments equals 0.484 , which is greater than 0.05 . This indicates that the fifth hypothesis was also not fulfilled.

Table 8. Effect of the Mozabook application on eLearning

\begin{tabular}{|l|c|c|c|l|}
\hline \multirow{2}{*}{ Dependent variable Independent variables } & \multicolumn{4}{c|}{ eLearning } \\
\cline { 2 - 5 } & $\boldsymbol{F}$ & $\boldsymbol{R}^{\mathbf{2}}$ & $\boldsymbol{B}$ & Impact indication \\
\hline Smart board & 44.244 & 0.371 & 0.706 & Moral \\
\hline Dynamic tools & 57.034 & 0.432 & 0.700 & Moral \\
\hline Applied tools & 68.170 & 0.476 & 0.743 & Moral \\
\hline Exercise \& homework & 46.893 & 0.385 & 0.654 & Moral \\
\hline Values & 51.204 & 0.637 & 0.652 & Moral \\
\hline
\end{tabular}

Table (8) displays several findings. Firstly, it shows that the value of R2 equals (0.371). This means that the variable of smartboard has been interpreted at a rate of $(37 \%)$ of the changes that occur to eLearning with a value of $(B=0.706)$. This means an increase of the variable Smartboard with one unit of standard deviations that will lead to an increase in eLearning by $7 \%$ of the standard deviation unit. Secondly, it indicates that the value of $\mathrm{R} 2$ is equal to $(0.432)$. This means that the dynamic additions have explained the percentage $(43 \%)$ of the changes that occurred to eLearning with a value of $(B=0.7)$. This means an increase of the dynamic additions' variable with one unit of standard deviations will lead to an increase in eLearning by $7 \%$ of the standard deviation unit. Thirdly, it shows that the value of R2 is equal to 
(0.476). This means that the applied tools have interpreted a ratio of $(47.6 \%)$ of the changes that occurred to eLearning. It also means that the value reached $(B=0.743)$, that is an increase in the variable of applied tools with one unit of standard deviations will lead to an increase in the sustainability education by $7.43 \%$ of the unit standard deviation. Fourthly, it indicates that the value of R2 equals $(0.385)$. This means that homework and exercises have interpreted a percentage of $(38.5 \%)$ of the changes in eLearning, with a value of $(\mathrm{B}=0.654)$. This means an increase in the exercise and homework variable with one unit of standard deviations will lead to an increase in sustainability education by $65.4 \%$ of the standard deviation unit. Fifthly, it shows that the value of $\mathrm{R} 2$ is equal to (0.637). This means that the evaluation has interpreted a rate of $(63.7 \%)$ of the changes that occur to eLearning with a value of $(\mathrm{B}=0.652)$. This means an increase of the evaluation variable with one unit of the standard deviations will increase the eLearning by $6.52 \%$ of the standard deviation unit.

\section{Conclusions and Recommendations}

\subsection{The demographic variables}

The participation rate of the age groups in the program was from 35-44 years, standing for $23.4 \%$. This shows that the percentage of academics is among the early age bracket that can be relied upon in eLearning and its development in the future. The percentage of males taking part in the program was $68.8 \%$, while the percentage for females stood at $31.2 \%$. The percentage of the participants in the program with years of service ( 25 years) was $23.4 \%$. This percentage is reasonable and logical as it has experience and development in the eLearning curriculum.

\subsection{The Mozabook (Digital Education)}

The arithmetic mean for the dimensions of the Mozabook digital learning is 3.83 . The standard deviation is 0.589 , while the relative significance is $76.6 \%$. The direction of the answer is (agreed), as shown in Table (2). The arithmetic mean values obtained for dynamic additions, smartboard, applied tools, exercises and homework, evaluation dimensions stood at $(3.96,3.75,3.79,3.82,3.91)$. The standard deviation values were $(0.687,0.632,0.679,0.895,0.715)$. The percentage weight values were $(78.4 \%, 75 \%, 74.8 \%, 76.4 \%, 78.2 \%)$, i.e. greater than $60 \%$. This shows that there is a strong indication of this dimension. The MozaBook application is of an immense value as it works on smartphones and tablets. This is in addition to the engineering software it contains, which are rotation representation programs for solid objects such as cones or balls. This in turn contributed to reducing the economic burden on the countries of the world. 


\section{3 eLearning axis}

We can also see evidence that shows an increase in the demand for adopting eLearning in higher education and at lower costs, especially after the emergence of the issues in the economy. Therefore, it has become an urgent necessity to push the path of higher education forward.

The dimensions of eLearning have registered an arithmetic mean value of 3.85 and 0.732 standard deviation, with a relative importance of $77 \%$, and that the direction of the answer is (agreed). The first major hypothesis, which states that there is a significant correlation between the application of the Mozabook digital education and electronic education was accepted while the null hypothesis was rejected. The value of the Pearson correlation coefficient was significant; equal to (0.744) as the value is sig. and equal to (0.000), which is less than 0.01 with $99 \%$ confidence. This means that the first main hypothesis is fulfilled, meaning there is a correlation between Mozabook and eLearning.

As for the sub-hypotheses, they run as follows: Significant correlation between smartboard, applied tools, dynamic additions, exercises and homework, evaluation, and eLearning in the study sample. The value of the Pearson correlation coefficient was significant and equal to $(0.609,0.690,0.657,0.62,0.609)$ given the value of sig. is equal to $(0.000)$, which is less than 0.01 , with a confidence of $99 \%$.

The second main hypothesis, which states that there is a significant effect of Mozabook application on eLearning, was accepted. The null hypothesis was rejected where the results of $\mathrm{F}$ test of education technological on sustainability education have shown a calculated $\mathrm{F}$ value of 93.23 ; insignificant at the 0.05 level. The $\mathrm{p}$. the value was (0.000), which is less than 0.05 and thus indicates there is an effect of Mozabook application on eLearning, as shown in Table 6 .

R2 value equals 0.55 ; this means that Mozabook digital education application explained a rate of $5.5 \%$ of the eLearning variable, as shown in Table (4). The effect value of (B) equals 0.926, meaning that an increase in the Mozabook application variable and one of the standard deviations will lead to an increase in eLearning by $9.26 \%$ of the standard deviation unit, as shown in Table 5 .

\section{Recommendations}

In view of the results of the study, we can make the following set of recommendations that need to be considered:

1. Providing modern technological devices at work (such as computers, the Internet, and the applications) that contribute to providing better, faster, and less expensive educational services for both parties.

2. Urging teachers and students to use technology by placing them in training workshops to get multiple skills in the basics of dealing with information and communication technology.

3. Paying more attention to the topic of eLearning, expansion of studies, and research related to it, and the need to develop cognitive and intellectual skills. 
4. Supplying the Internet to facilitate the exchange of information and experiences while focusing on interactivity and building solid communication channels for the transmission of knowledge.

5. Encouraging advanced experiences in the ministry to provide lectures and theoretical and practical discussions, and to hold workshops and development seminars.

6. Encouraging researchers and scholars to expand in the scientific analysis of the basic scientific concepts of digital education that contributes to the diagnosis and use of these variables accurately. This is because it is one of the important modern variables that have a significant impact on ensuring success in our time.

7. Making the eLearning variables (technology, educational environment, educational content) an approach that reflects the methods of management thinking in the ministry. This should be done in a way that makes a difference in the organization's level of strategic success.

\section{References}

[1] Kalogiannakis, M., Papadakis, S. (2017). A proposal for teaching ScratchJr programming environment in preservice kindergarten teachers. In Proceedings of the 12th Conference of the European Science Education Research Association (ESERA) (pp. 21-25).

[2] Kalogiannakis ,M.,Papadakis, S. (2019). Evaluating pre-service kindergarten teachers' intention to adopt and use tablets into teaching practice for natural sciences. International Journal of Mobile Learning and Organisation, 13(1), 113-127. https://doi.org/10.1504/ijm $\underline{\text { lo.2019.10016617 }}$

[3] Arkorful, V., Abaidoo, N. (2015). The role of e-learning, advantages and disadvantages of its adoption in higher education. International Journal of Instructional Technology and Distance Learning, 12(1), 29-42.

[4] AbdulRazak, N. S., Ali, M. A. (2019). Challenges of Implementation E-Learning Platforms in Iraqi Universities. Engineering and Technology Journal, 37(4C), 400-406.

[5] ALRikabi, H. T. S., Alaidi, A. H. M., Abed, F. T(2018). Attendance System Design And Implementation Based On Radio Frequency Identification (RFID) And Arduino. Journal of Advanced Research in Dynamical Control Systems,10(4),1342-1347.

[6] Papadakis, S. (2018). Evaluating pre-service teachers' acceptance of mobile devices with regards to their age and gender: a case study in Greece. International Journal of Mobile Learning and Organisation, 12(4), 336-352. https://doi.org/10.1504/ijmlo.2018.10013372

[7] Abed, F. T., ALRikabi, H. T. S., Ibrahim, I. A. (2020, June). Efficient Energy of Smart Grid Education Models for Modern Electric Power System Engineering in Iraq. In IOP Conference Series: Materials Science and Engineering (Vol. 870, No. 1, p. 012049). IOP Publishing. https://doi.org/10.1088/1757-899x/870/1/012049

[8] Al-Azawei, A., Parslow, P., Lundqvist, K. (2016). Barriers and opportunities of e-learning implementation in Iraq: A case of public universities. The International Review of Research in Open and Distributed Learning, 17(5). https://doi.org/10.19173/irrodl.v17i5.25 $\underline{01}$

[9] Elameer, A. S., Idrus, R. M. (2010, December). Modified Khan eLearning Framework for the Iraqi Higher Education. In The Seventh International Conference on eLearning for Knowledge-Based Society (pp. 16-17). 
[10] Alrikabi, H. T., Alaidi, A. H. M., Abdalrada, A. S., Abed, F. T. (2019). Analysis the Efficient Energy Prediction for 5G Wireless Communication Technologies. International Journal of Emerging Technologies in Learning (iJET), 14(08), 23-37. https://doi.org/10.39 91/ijet.v14i08.10485

[11] Aljazaery, I. A., Alrikabi, H. T. S., Aziz, M. R. (2020). Combination of Hiding and Encryption for Data Security. iJIM, 14(9), 34-47. https://doi.org/10.3991/ijim.v14i09.1417 $\underline{3}$

[12] Alaidi, A., Yahya, O., Alrikabi, H. (2020). Using Modern Education Technique in Wasit University, iJIM , 14(06), 82-94. https://doi.org/10.3991/ijim.v14i06.11539

[13] Papadakis, S., Kalogiannakis, M. (2018). Evaluating a course for teaching advanced programming concepts with scratch to preservice kindergarten teachers: a case study in Greece. In Early Childhood Education. IntechOpen. https://doi.org/10.5772/intechopen.8 $\underline{1714}$

[14] Malikowski, S. R., Thompson, M. E., Theis, J. G. (2007). A model for research into course management systems: Bridging technology and learning theory. Journal of educational computing research, 36(2), 149-173. https://doi.org/10.2190/1002-1t50-27g2-h3v7

[15] Hussien, N., Ajlan, I., Firdhous, M. M., Alrikabi, H. (2020). Smart Shopping System with RFID Technology Based on Internet of Things, iJIM , 14(04), 17-29. https://doi.org/10.39 91/ijim.v14i04.13511

[16] Papadakis, S., Kalogiannakis, M., Sifaki, E., Vidakis, N. (2017). Access moodle using smart mobile phones. A case study in a Greek University. In Interactivity, Game Creation, Design, Learning, and Innovation (pp. 376-385). Springer, Cham. https://doi.org/10.1007/9 78-3-319-76908-0 36

[17] Emmer, E. T., Stough, L. M. (2001). Classroom management: A critical part of educational psychology, with implications for teacher education. Educational psychologist, 36(2), 103-112. https://doi.org/10.1207/s15326985ep3602_5

[18] Davis, C. H., Comeau, J. (2020). Enterprise integration in business education: Design and outcomes of a capstone ERP-based undergraduate e-business management course. Journal of Information Systems Education, 15(3), 8.

[19] Becker, S. A., Cummins, M., Davis, A., Freeman, A., Hall, C. G., Ananthanarayanan, V. (2017). NMC horizon report: 2017 higher education edition (pp. 1-60). The New Media Consortium.

[20] Mahdavinasab, Y., Sadipour, E., Moradi, M. (2019). An Investigation of the Effective Components Considered in Designing E-Learning Environments in Higher Education and Offering a Framework for E-Learning Instructional Design. Quarterly Journal of Iranian Distance Education, 1(4), 9-24.

[21] Bossetta, Michael. "The digital architectures of social media: Comparing political campaigning on Facebook, Twitter, Instagram, and Snapchat in the 2016 US election." Journalism \& mass communication quarterly 95.2 (2018): 471-496. https://doi.org/10.11 77/1077699018763307

[22] Papadakis, S., Kalogiannakis, M. (2019). Evaluating a course for teaching introductory programming with Scratch to pre-service kindergarten teachers. International Journal of Technology Enhanced Learning, 11(3), 231-246. https://doi.org/10.1504/ijtel.2019.100478

[23] Papadakis, S. (2018). Evaluating pre-service teachers' acceptance of mobile devices with regards to their age and gender: a case study in Greece. International Journal of Mobile Learning and Organisation, 12(4), 336-352. https://doi.org/10.1504/ijmlo.2018.10013372

[24] Bernard, R. M., Borokhovski, E., Schmid, R. F., Tamim, R. M., Abrami, P. C. (2014). A meta-analysis of blended learning and technology use in higher education: From the 
general to the applied. Journal of Computing in Higher Education, 26(1), 87-122. https:// doi.org/10.1007/s12528-013-9077-3

[25] Chigeza, P., Halbert, K. (2014). Navigating E-Learning and Blended Learning for PreService Teachers: Redesigning for Engagement, Access and Efficiency. Australian Journal of Teacher Education, 39(11), n11. https://doi.org/10.14221/ajte.2014v39n11.8

[26] Southard, S., Meddaugh, J., France-Harris, A. (2015). Can SPOC (Self-Paced Online Course) live long and prosper? A comparison study of a new species of online course delivery. Online Journal of Distance Learning Administration, 18(2).

[27] Putri, I. G. A. V. W. (2019). Students' Influences of CAA: A Case Study of Senior High School in Badung Bali. International Journal for Educational and Vocational Studies, 1(1), 1-4. https://doi.org/10.29103/ijevs.v1i1.1392

[28] Binyamin, S. S., Rutter, M., Smith, S. (2019). Extending the technology acceptance model to understand students' use of learning management systems in Saudi higher education. International Journal of Emerging Technologies in Learning (iJET), 14(03), 4-21.

Chang, V. (2016). Review and discussion: E-learning for academia and industry. International Journal of Information Management, 36(3), 476-485. https://doi.org/10.3991/ ijet.v14i03.9732

[29] Bondarenko, O. V., Pakhomova, O. V., Zaselskiy, V. I. (2019). The use of cloud technologies when studying geography by higher school students. arXiv preprint arXiv:1909.04377.

[30] Wiphasith, H., Narumol, R., Sumalee, C. (2016). The design of the contents of an elearning for teaching M. 5 English language using ADDIE model. International Journal of Information and Education Technology, 6(2), 127. https://doi.org/10.7763/ijiet.2016.v6.67 $\underline{1}$

[31] Good, T. L., Lavigne, A. L. (2017). Looking in classrooms. Routledge.

[32] Bajner, M. (2019). Teaching on the Run-Learning on the Go. KÉPZÉS ÉS GYAKORLAT: TRAINING AND PRACTICE, 17(2), 7-20. https://doi.org/10.17165/tp.2019.2.1

[33] Yahya, O. H., Alrikabi, H., Aljazaery, I. A. (2020). Reducing the Data Rate in Internet of Things Applications by Using Wireless Sensor Network. International Journal of Online and Biomedical Engineering (iJOE), 16(03), 107-116. https://doi.org/10.3991/ijoe.v16i03. 13021

[34] Simonson, M., Zvacek, S. M., Smaldino, S. (2019). Teaching and Learning at a Distance: Foundations of Distance Education 7th Edition. IAP.

[35] Mohammed, B., Chisab, R., Alrikabi, H. (2020). Efficient RTS and CTS Mechanism Which Save Time and System Resources, iJIM , 14(04), 204-2011. https://doi.org/10.3991/ijim.v14i04.13243

[36] Ma'ruf, A., Ibrahim, N., Syahrial, Z. (2020). Development of Online Materials in the Subject Course Analysis and Data Utilization on the NFPPB Training Center. KOLOKIUM: Jurnal Pendidikan Luar Sekolah, 8(1), 7-29.

\section{Authors}

Duha Khalid Abdul-Rahman Al-Malah: Lecturer, is the Reporter Department of Tourism and Hotel Management, Responsible of the Central Library Division, Instructor for Computer Applications Course in Administrative Technical College, Northern Technical University, Mosul, Iraq. 
Saad Ibrahim Hamed: He is an Assistant Professor Saad Ibrahim Hamed and the Head of the Department of Tourism and Hotel Management, Director of the Quality Assurance Division, and Chairman of the Promotion Committee at the Administrative in Nenawa Institute, Northern Technical University, Mosul, Iraq.

Haider Th. Salim ALRikabi, Asst. Prof., he is presently one of the faculty college of engineering, electrical engineering department, Wasit University in Al Kut, Wasit, Iraq. He received his B.Sc. degree in Electrical Engineering in 2006 from the Al Mustansiriya University in Baghdad, Iraq. his M.Sc. degree in Electrical Engineering focusing on Communications Systems from California state university/Fullerton, USA in 2014. His current research interests include Communications systems with mobile generation, Control systems, intelligent technologies, smart cities, and Internet of Things (IoT).

Article submitted 2020-07-17. Resubmitted 2020-08-09. Final acceptance 2020-08-09. Final version published as submitted by the authors. 